\title{
ACHIEVING GENDER EQUALITY IN EDUCATION IN CIVIL ENGINEERING IN MONTENEGRO
}

\author{
Mladen Perazić* \\ Chamber of Economy of Montenegro, Podgorica, Montenegro \\ Nevenka Pavličić \\ Clinical Center of Podgorica, Podgorica, Montenegro \\ Miloš Knežević \\ University of Montenegro, Faculty of Civil Engineering, Podgorica, Montenegro
}

Achieving gender equality in the process of education is a long procedure which resulted in the fact that the level of education of women in Montenegro has long been equated with the level of education of men. Thus, equal gender opportunities in employment should come as a result of such situation. However, data show that women are failing, as much as men, to ensure a successful career. In recent years, the situation in education in civil engineering has been changed for the better, and in this sense the women occupy an appropriate position in this field of economy.

Key words: Education, Equality, Civil engineering

\section{INTRODUCTION}

Education is the process where people develop their abilities and skills for life and work. It prepares the individuals for inclusion into society and gives them the opportunity for positioning in the world of work and in the community. Education is a constant process of achieving spiritual values which continues during the course of life through the activities of informal, non-formal and formal education. The influence of education process on the shaping of personality and the whole society is an immeasurable factor in development of the country. Transformation and changes in education are the reflection of changes in the society, because education is a driving force of development and one of the main factors that influence the forming of values in society.

Achieving the gender equality in the process of education is a long procedure which resulted in the fact that the level of education of women in Montenegro has long been equated with the level of education of men. Equal gender opportunities in employment should come as a result of such situation, given that education is defined as the most important factor of vertical mobility and as powerful instrument for prevention of social exclusion. However, the data show that women fail to provide high quality employment and successful careers to the same extent as men. Women are still on the margins of the mainstream of society. The cause and outcome of that is an unequal distribution of powers and the rights they have. All this leads to the keeping of traditional culture, negative aspects of patriarchal culture and further economic underdevelopment of society. Given that women represent more than $51 \%$ of the population of Montenegro, the importance of proper education of this part of population is of the key importance for the development of human resources, and thus of the national economy. Valuable and cultural system of a country, the culture of a learning society, the efforts to create the knowledge economy, are the basic infrastructural precondition for the growth, development and creation of a society which is worthy of a man. The condition for the creation of a learning society is the recruitment of all possible stakeholders in the society, especially women who represent $51.6 \%$ of the total population of Montenegro, what is more than a half in all countries of the world. In modern education systems the impartiality, the standards of values of knowledge, achievements and capabilities of individuals are respected, regardless of the gender. Modern development implies that the knowledge is the basis of social and economic growth, and education leads to the knowledge. In this respect, education is the solid foundation and the support of each country. The educational level of the population is an inevitable factor of the level of social development of a community. 


\section{EDUCATION AND SOCIETY}

Insufficient involvement of women in education throughout history has resulted in a huge nonuse of human resources potentials. Thus, if we define education as a socio-historical phenomenon and activity which represents a conscious and continuous aspiration of the community to qualify its members for tasks that are put before society and individuals, the target that all members of society are involved in this process was achieved during the $20^{\text {th }}$ century. $\mathrm{H}$. Gudjons [01], states that education means:

- training for rational self-determination,

- development of entities in the media and the objectification of previous human culture,

- productive participation in culture,

- achievement of individuality and sociability,

- generally valid, i.e. equally valid education for all people,

- versatility - moral, cognitive, aesthetic and practical dimension.

Learning and education processes were present throughout the whole history of mankind, and as society evolved, these processes were becoming more complex and organized. The first teachers were women who were transferring their knowledge to descendants. Nowadays, new knowledge and education systems which are adapted to each person are needed for the survival of civilization and society. Without education every society would degrade, and people would become uncivilized and they would imperil the survival of resources on the planet by their demographic growth. P. Gazivoda points out that the preservation and usage of natural resources can only be provided with a huge investment of knowledge and capabilities of all inhabitants of our planet and that only education is able to come to an effective and lasting solutions to the issues regarding dignity of man and woman, as well as the conditions of their existence [02]. The existence of man, the preservation of the planet, the rational use of resources is closely linked to raising the level of education of the population. Thus, prof. D.M. Savićević, PhD, notes that the modern world is characterized by a high degree of interdependence in the areas of economy, politics, technology, science and culture, and education is an area of a spiritual activity where such interdependence is particularly evident [3]. Qualities such as humanity, empathy, communication skills and vocational education are developed through the process of education. In the market competition of modern economy, the countries are trying to organizationally develop these qualities in its citizens through educational systems. The process and result are integrated into education which stands out. Bojan K. Lazarević is recognized in almost all spheres of human activity and, as such, by itself, assumes an essential element of development of an individual, no matter from which aspect it is observed [04].

The research has found that there is a high degree of correlation between an increased level of education and economic growth of the country. Educational institutions and educational level of the population does not affect only the creation of human capital, but also the strengthening of social capital. Still, women represent more than a half of the social capital in every society. However, as the environment is increasingly changing, education of the workforce should be a continuous process, since a large number of people with outdated diplomas are not the basis for economic growth. The practice of transition countries showed that women were more flexible and more willing to learn and acquire new knowledge and they easily find their place in the labor market. What is the scope of an impact of education on gender relations and women's emancipation nowadays points out also $Đ$. Šušnjić, who finds that a reasonable (and human) education system must meet the following five conditions: To convey the cultural heritage and traditions to the young generation, to prepare young people to take over some of the existing working roles, to create value awareness or conscience of young people, to develop the capabilities of each individual, to develop a relationship of educational system toward the exceptional and gifted persons and geniuses. Importance of developing value awareness of education is the foundation of later attitude towards the emancipation and professional accomplishment of women. Zhou Nanzhao points out that the role of education and culture is the development which aims to flourishing of human potential worldwide [4]. N. Mujić explains the role of the educational systems at the present time stating that new demands are set before the educational systems: focusing of education on the purpose, openness of the education system, continuity of education, education outside schools, social responsibility of education. The Report of the UNESCO International 
Commission on the Development of Education for the Twenty-first Century highlights that education is at the heart of the development of both individuals and communities, its mission is to enable each of us, without exception, to fully develop all of our talents and to achieve our creative potential, including responsibility for the personal lives and achievement of personal goals. [5] It is also stated that, in dealing with the many challenges that are waiting for us in the future, the humankind sees in education an indispensable wellbeing in the attempt to achieve the ideals of peace, freedom and social justice [06].

In the knowledge economy, education primarily promotes social inclusion of all individuals and develops their skills in order to increase their employability. An inclusion of all individuals and social groups is emphasized in order to promote their rights. Employability represents the competitiveness of knowledge, skills and abilities of individuals in the labor market. Employability is acquired by constant modernization of existing knowledge and skills and by further education, thus making easier to find a new job. J. Denison believes that an efficient education system enables training of enough people to vital skills in order to adequately contribute to economic growth in a new industrial society. At the same time the system must provide an opportunity for those in the workplace to improve their skills and fill their intellectual competitiveness in order to adapt to changes in technology [07]. This is very important as it allows a woman to reconcile her career with a role in the family and to improve her skills by flexible ways of constant trainings. Versatile and flexible offer of educational services aims to better meet the changing and heterogeneous demand. In addition to schools, various education institutions for adults are engaged for this purpose, provided that they meet the criteria in terms of quality of education. In the world, the market of educational services is very developed [08].

\section{THE WAY TOWARDS EQUAL OPPORTUNITIES FOR EDUCATION IN MONTENEGRO}

As well as the in other European countries, the development path of achieving gender equality in Montenegro has been long and difficult. The period after World War II in Montenegro was followed by great social, political and economic changes. There was a massive urbanization and emancipation of rural areas and populations, as well as general industrialization. These changes greatly affected the lives, rights and status of women in society. Women's rights were legalized by the legislation which encouraged emancipation and equality with men. In the first Constitution of the Federal Republic of Yugoslavia (FNRY) in 1946, women were formally granted the right to vote. Article 24 states that, all citizens, regardless of gender, ethnicity, race, religion, level of education, place of residence and who are over 18, have the right to elect and to be elected to all bodies of state power. In a new system women have succeeded, within the new ideology, to actively transform relations between the sexes, to establish the equality. All international conventions referring to the status of women were incorporated in the former Yugoslav legislation. Regardless of progressive legal solutions and the establishment of kindergartens and child care centers, female role of a mother and primary educator of children, as well as of one who takes care of the house and chores, was never really challenged. Following the end of World War II the most dynamic period of development of education in Montenegro begins. The Law on Primary Education, adopted in 1959, required the compulsory attendance of primary school by male and female citizens who were 7 to 15 years old. When it comes to high schools, the big problem was the lack of a developed network of schools for vocational education. Because of the patriarchal system of values the parents are unwilling to send their female children out of the place of residence. The number of women who enrolled the colleges and faculties increased in proportion to the enlarged number of faculties and colleges. Women mostly enroll teaching faculties, while a smaller number enroll the law, economics, etc. After the disintegration of FNRY the status of women has got worse. The economic crisis, the disintegration of Yugoslavia, the fall of socialism and the transition processes, they all have had negative consequences for women in Montenegro, returning them to the framework of their biological role - mother, but also to the private area - house. Women's role has been downgraded to the one that is dominant in patriarchal societies and the equality that socialist women won and gained was rapidly forgotten and annulled except in the education segment where they have experienced the greatest emancipation. The implementation of the concept of equality in 
education in Montenegro has led, in the past 50 years, to the fact that there is no difference in the rate of enrollment of boys and girls in primary school ( $98.4 \%$ of boys and $98 \%$ of girls attend primary school), so at the primary level of education the gender inequality has been practically eliminated. The differences in education between men and women do not exist even in respect of secondary education. At higher levels of education, the trend of increasing participation of young women has been developed where the percentage of female students even exceeds the percentage of male students, but this advantage is lost at postgraduate studies.

Given that the civil engineering and tourism are strategic sectors in Montenegro, one cannot fail to notice that an issue of deficiency is the most obvious problem in these sectors because they make over half of the demand for workforce by employers, as well as the fact that foreign workers are mostly being employed. As regards the qualification of III level of education there is a deficiency of: carpenters, masons, reinforcing iron workers, construction machinery operators, pavers, insulation workers, plasterers, facade plasterers, tilers and installers of floors, while at the qualification of IV level of education an issue of deficiency is dominant in construction technicians, then surveying technicians, technicians for the civil engineering construction and building construction, as well as building surveyors. As regards the qualification of VII level of education, graduated engineers of geodesy are the most needed, then the engineers of architecture and civil engineers. This is supported by the fact that the geodesy and architecture started to work as independent programs merely since 2006 in Montenegro.

\section{ACHIEVING GENDER EQUALITY IN EDUCA- TION IN CIVIL ENGINEERING}

The equal right to education and equal access to education are the basis for the achievement of equal opportunities for professional career and for the realization of personal potentials of both men and women. These rights in Montenegro are guaranteed at all levels of education. There are no differences in schools and school subjects that are available for girls and boys. The legislation has no gender discriminatory provisions in the laws governing education, but there is no specific gender sensitivity, not in terms of the content of school curricula or regarding the language.

Table 1: The percentage of students in the total number of primary and high schools in Montenegro

\begin{tabular}{|c|c|c|c|c|c|c|}
\hline & \multirow{3}{*}{ Schools } & \multirow{3}{*}{ Classes } & \multicolumn{4}{|l|}{ Students } \\
\hline & & & \multirow{2}{*}{ Total } & \multirow{2}{*}{$\begin{array}{l}\text { Female } \\
\text { students }\end{array}$} & \multicolumn{2}{|c|}{ Finished school year } \\
\hline & & & & & Total & Female students \\
\hline Regular primary education 1) & 435 & 3318 & 70222 & 33896 & 8426 & 4104 \\
\hline Regular secondary education 2) & 49 & 1140 & 31388 & 15515 & 8447 & 4066 \\
\hline
\end{tabular}

Source: Statistical Office of Montenegro, Statistical Yearbook of Montenegro 2012

Table 2: Regular male/female students in high schools

\begin{tabular}{|c|c|c|c|c|c|}
\hline \multirow{2}{*}{ School year } & \multicolumn{3}{|c|}{\begin{tabular}{c}
\multirow{2}{*}{ High schools (I - IV) } \\
\multirow{2}{*}{ Primary schools (1- IV) }
\end{tabular}} \\
\cline { 2 - 6 } & Total & girls & boys & girls & boys \\
\hline $2009 / 2010$ & 31643 & 15626 & 1607 & 49,4 & 50,6 \\
\hline $2010 / 2011$ & 32126 & 15632 & 16494 & 48,7 & 51,3 \\
\hline $2011 / 2012$ & 31914 & 15633 & 16281 & 49,0 & 51,0 \\
\hline $2012 / 2013$ & 31858 & 15584 & 16274 & 48,9 & 51,1 \\
\hline
\end{tabular}

Source: Ministry of Human and Minority Rights of Montenegro and Statistical Office of Montenegro (2014), Women and Men in Montenegro 
Table 3: Enrolled male/female students (undergraduate studies)

\begin{tabular}{|c|c|c|c|c|c|}
\hline \multirow{2}{*}{ School year } & \multirow{2}{*}{ Total } & \multirow{2}{*}{ Women } & \multirow{2}{*}{ Men } & \multicolumn{2}{|c|}{ Gender distribution\% } \\
\cline { 5 - 6 } & & & women & men \\
\hline $2009 / 2010$ & 21199 & 11268 & 9931 & 53,2 & 46,8 \\
\hline $2010 / 2011$ & 22163 & 11748 & 10415 & 53,0 & 47,0 \\
\hline $2011 / 2012$ & 22227 & 11956 & 10271 & 53,8 & 46,2 \\
\hline $2012 / 2013$ & 22279 & 11882 & 10397 & 53,3 & 46,7 \\
\hline
\end{tabular}

Source: Ministry of Human and Minority Rights of Montenegro and Statistical Office of Montenegro (2014),

Women and Men in Montenegro

During 2012, 2923 students have graduated at the undergraduate studies. Of the total number of graduated students at the undergraduate studies, $60.5 \%$ were female and $39.5 \%$ male students. During 2012, 282 students have completed the master studies, of which $63.5 \%$ were female and $36.5 \%$ male students.

Gender inequality is also reflected in the segregation of educational profiles, where the traditional division into "male" and "female" professions still prevails. The female students are mostly enrolled at faculties of social sciences and faculties of art, while technical colleges are dominated by men. Traditionalism in relation to gender roles results in a higher technical illiteracy of women, which later additionally marginalizes them in the labor market. As regards the professions in Montenegro in civil engineering there are 23 high schools and 3 faculties for education of personnel in the field of civil engineering, who study for qualification of IV level of education: technician for building construction, technician for civil engineering construction, technician for hydraulic engineering, technician of architecture and geodetic technician - land surveyor. As regards the qualification of III level of education, in the Montenegrin formal education system there are no conditions for education of: tinsmiths, tilers, locksmiths, welders, operators of heavy machinery, installers, installers of sanitary appliances and air conditioners, hydro-civil engineer, electrician, installer of dry material. In the system of higher education, there are five faculties in Montenegro for education of personnel for construction purposes, such as: Faculty of Civil Engineering, Faculty of Architecture, Geodesy, Faculty of Electrical Engineering and Faculty of Mechanical Engineering.

When analyzing enrollment by gender at the Faculty of Civil Engineering of the University of Montenegro, we may note the growth of enrollment of students in recent years.

Table 4: Enrolled male/female students at the Faculty of Civil Engineering (undergraduate studies)

\begin{tabular}{|l|c|c|c|c||}
\hline Undergraduate studies & $\begin{array}{c}\text { School year } \\
2012 / 2013\end{array}$ & $\begin{array}{c}\text { School year } \\
2013 / 2014\end{array}$ & $\begin{array}{c}\text { School year } \\
2014 / 2015\end{array}$ & $\begin{array}{c}\text { School year } \\
2015 / 2016\end{array}$ \\
\hline Women: & 43 & 77 & 97 & 63 \\
\hline Men: & 104 & 121 & 109 & 97 \\
\hline Enrolled: & 147 & 198 & 206 & 160 \\
\hline
\end{tabular}

Source: Student Administration Office of the Faculty of Civil Engineering

\section{CONCLUSION}

The level of education of women in Montenegro has long been equated to the education of men. In the field of civil engineering the situation has been improved in recent years, although it is still dominated by men. Equal gender opportunities in employment should come as a result of such situation, given that education is defined as the most important factor of vertical mobility and as powerful instrument for prevention of social exclusion. However, the data show that women fail to provide high quality employment and successful careers to the same extent as men. Certain industries and professions are still hardly accessible to women, although the situation in civil engineering has been changed to the better. Inherited inequality and the issue of women from the previous period are still being conveyed further. 
Women in Montenegro are faced with different barriers in vertical mobility, what resulted in their weaker professional aspirations and choosing of stereotyped occupations. The deficiency of women in leading positions, as well as in owing properties and business entities, shows their position in society. Education is one of the main factors that influence the key obstacles to achieving gender equality in Montenegro and overcoming the rooted stereotypes on the educational choices of women for acquiring appropriate, technologically advanced and economically promising qualifications.

\section{REFERENCES}

1) H. Gudjons, „Pedagogy: basic knowledge“, Educa, Zagreb, 1993, p. 162

2) P. Gazivoda: „Educational vibrations“, Institute for Textbooks and Teaching Aids, Podgorica, 2006. p. 128

3) D. M. Savićević: „Comparative andragogy“, Institute of Pedagogy and Andragogy, Faculty of Philosophy in Belgrade, Belgrade 2003, p. 23
4) B. K. Lazarević: „With education to recreation", Adult Education Society, Belgrade 2007, p. 1

5) J. Delors...et al.: „Learning: The Treasure Within", Report of the UNESCO International Commission on the Development of Education for the Twenty-first Century, Educa, Zagreb 1998, p. 269-281

6) J. Delors...et al.: „Learning: The Treasure Within", Report of the UNESCO International Commission on the Development of Education for the Twenty-first Century, Educa, Zagreb 1998, p. 19

7) J. Delors...et al.: „Learning: The Treasure Within“, Report of the UNESCO International Commission on the Development of Education for the Twenty-first Century, Educa, Zagreb 1998, p. 13

8) J. Denison: „Technology, higher education and economy - a critical attitude". The ways of education - foreign experiences, Saša Nedeljković, Belgrade 1991, p. 101-111

Paper sent to revision: 28.01.2016.

Paper ready for publication: 03.03.2016. 
doi:10.5937/jaes14-10468

Broj rada: 14(2016)1, 366

\section{POSTIZANJE RODNE RAVNOPRAVNOSTI U OBRAZOVANJU} U GRAĐEVINARSTVU U CRNOJ GORI

\section{Mladen Perazić, Privredna komora Crne Gore Nevenka Pavličić, Privredna komora Crne Gore Miloš Knežević, Privredna komora Crne Gore}

Postizanje rodne ravnopravnosti u procesu obrazovanja je dugotrajan postupak koji je rezultirao činjenicom da se nivo obrazovanja žena u Crnoj Gori već dugo izjednačava sa nivoom obrazovanja muškaraca. Tako, jednake mogućnosti polova u zapošljavanju bi trebalo da bude rezultat takve situacije. Međutim, podaci pokazuju da su žene neuspešne, koliko i muškarci, kako bi se osiguralo uspešnu karijeru. U poslednjih nekoliko godina, situacija u obrazovanju u građevinarstvu je promenjena na bolje, i u tom smislu žene zauzimaju odgovarajuće pozicije u ovoj oblasti privrede.

Ključne reči: Obrazovanje, Kvalitet, Građevinarstvo 